\title{
Crosslinking of Casein Components by Transglutaminase*
}

\author{
Koji Ikura, Takashi Kometani, Masaaki Yoshikawa, \\ Ryuzo SASAKI and Hideo CHIBA \\ Department of Food Science and Technology, Faculty of Agriculture, \\ Kyoto University, Kyoto 606, Japan
}

Received January 24, 1980

\begin{abstract}
Transglutaminase catalyzes the formation of $\varepsilon$-( $($-glutamyl)lysyl crosslinks and the substitution of a variety of primary amines for the $\gamma$-carboxyamide groups of protein-bound glutaminyl residues. As a first step in the use of transglutaminase for enzymic modification of food proteins, the reactivity of bovine casein components $\left(\alpha_{\mathrm{s}^{-}}, \beta\right.$-, and $\kappa$-caseins) in the transglutaminase reaction was compared, and the properties of casein modified by this enzyme were examined.

The reactivity of $k$-casein was lower than that of $\alpha_{\mathrm{s} 1}$ - or $\beta$-caseins. Sodium dodecyl sulfatepolyacrylamide gel electrophoresis analysis indicated that each casein component was polymerized through formation of intermolecular crosslinks by transglutaminase.

Ultracentrifugal experiments in the absence of calcium ions revealed that complex formation between $\alpha_{\mathrm{s} 1}$-casein (or $\beta$-casein) and $\kappa$-casein was not impaired by this modification. The functional properties of $\alpha_{\mathrm{s1}}$ and $\beta$-caseins in the presence of calcium ions (e.g. precipitation and micelle formation) were essentially retained after the modification. These results suggest that transglutaminase would be a useful tool to polymerize casein without damaging its special properties.
\end{abstract}

Transglutaminase catalyzes a calciumdependent acyl-transfer reaction in which the $\gamma$-carboxamide groups of peptide-bound glutaminyl residues are the acyl donors. Primary amino groups in a variety of compounds may act as acyl acceptors with the subsequent formation of monosubstituted $\gamma$ amides of peptide-bound glutamic acid. ${ }^{1}$ )

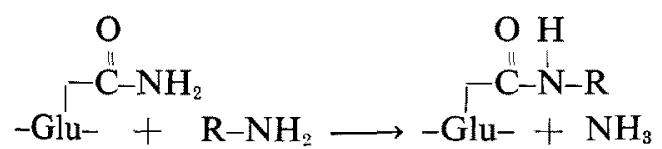

If $\mathrm{R}-\mathrm{NH}_{2}$ is a suitable exogeneously added amine, appropriate $R$ groups can be introduced to the protein at the glutaminyl residue. $\varepsilon$-Amino groups of appropriate lysyl residues in proteins can also serve as substrates, generating intra- or intermolecular $\varepsilon-(\gamma$-glutamyl) lysyl crosslinks (isopeptide bonds).

Transglutaminases are widely distributed in nature ${ }^{1,2)}$ and several of them have been

* This study was supported by Grant-in-Aid for Scientific Research from the Ministry of Education, Science and Culture. shown to perform biologically important functions by catalyzing the formation of $\varepsilon-(\gamma$ glutamyl)lysyl crosslinks with protein substrates. These functions include the stabilization of the fibrin structure during blood coagulation, ${ }^{3)}$ the clotting of seminal fluid, ${ }^{4}$ the stiffening of the erythrocyte membrane, ${ }^{5)}$ and the formation of the cornifying envelope in keratinocytes. ${ }^{6}$. The occurrence of the $\varepsilon$ ( $\gamma$-glutamyl)lysyl crosslink and its physiological role have been the subjects of a recent review. ${ }^{2}$

The capacity to mediate the attachment of specific labels to proteins, and to introduce crosslinks between them, should make transglutaminase very useful for effecting specific modifications of proteins and for the analysis of protein structure and organization. Some reports have indicated that transglutaminase is generally useful in crosslinking membrane proteins and in attaching to them a variety of chemical probes and labels. These studies involve the membranes of mouse ${ }^{7)}$ and human ${ }^{8,91}$ erythrocytes, of sarcoplasmic reticulum from rabbit skeletal muscle, ${ }^{7,9,10}$ of human plate- 
lets ${ }^{11)}$ and of bovine retinal rod.9,12) Transglutaminase has also been used to label viral proteins $^{g, 13)}$ and skeletal muscle myofibril proteins. ${ }^{14)}$

The demand for high quality food protein is increasing. Modification of proteins with enzymes or chemical reagents helps improve the functional properties and nutritive values of currently available food proteins. ${ }^{15}$ Enzymic modification has a great advantage in that we need not have much concern about the production of unknown components which may be toxic, because enzyme-catalyzed reactions proceed specifically under mild conditions. Although a number of enzymes which modify proteins have been found, few papers have appeared describing the use of enzymes other than hydrolases to produce food protein of high quality.

It has been shown that bovine casein is a good substrate for various transglutaminases in the presence or the absence of added amines. The properties of modified casein, however, have not been reported. In this study, the reactivities of purified bovine casein components ( $\alpha_{\mathrm{s} 1^{-}}, \beta$-, and $\kappa$-caseins) in the transglutaminase reaction catalyzed by guinea pig liver enzyme were compared, and the properties of the casein components modified by the enzyme were examined.

\section{MATERIALS AND METHODS}

Transglutaminase. Transglutaminase was purified from fresh guinea pig livers by the method of Connellan et $a l^{16)}$ During the purification, enzyme activity was determined by a colorimetric hydroxamate procedure using an ethanol extract of a tryptic digest of casein as substrate. ${ }^{17)}$ The prepared enzyme exhibited $95 \%$ of the reported specific activity upon assay by hydroxamate formation with $N$-carbobenzoxy-L-glutaminylglycine, ${ }^{18)}$ and gave a single band on electrophoresis in a polyacrylamide gel containing SDS.* This sample exhibited no proteolytic activity. The enzyme was stored at $-80^{\circ} \mathrm{C}$ in $0.4 \mathrm{ml}$ aliquots. An extinction coefficient of $E_{280 \mathrm{~nm}}^{1 \%}=15.8^{10)}$ was used to determine the enzyme concentration.

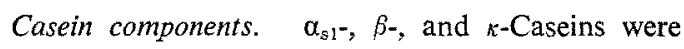

* SDS, sodium dodecyl sulfate. prepared by the methods described in a previous paper. ${ }^{19)}$ The number of lysyl residues was 14 for $\alpha_{\mathrm{s} 1}$-casein, ${ }^{20,21)} 11$ for $\beta$-casein, ${ }^{21,22)}$ and 9 for $\kappa$ casein. $^{23)}$ Values of $23,500,24,000$, and 19,000 were used for the monomer molecular weights of $\alpha_{s 1^{-}}, \beta$, and $k$-caseins, respectively.

Chemicals. A tryptic digest of casein ( $N$-Z-Amine Type E) was obtained from Humko Sheffield. $N$ Carbobenzoxy-L-glutaminylglycine was from Vega Biochemicals. L-Glutamate dehydrogenase (Type In) was from Sigma. The molecular weight calibration kit (HMW) was from Pharmacia Fine Chemicals. Other reagents (of guaranteed reagent grade) were purchased from Wako Pure Chemical Industries, Ltd. and from Nakarai Chemicals, Ltd.

Crosslinking. The standard reaction mixture contained, in a total volume of $100 \mathrm{ml}, 0.1 \mathrm{M}$ Tris- $\mathrm{HCl}$ buffer (pH 7.5), $5 \mathrm{~mm} \mathrm{CaCl}, 10 \mathrm{mM}$ dithiothreitol, $5 \mathrm{mg} / \mathrm{ml}$ casein component, and $30 \mu \mathrm{g} / \mathrm{ml}$ transglutaminase. Incubations were performed at $25^{\circ} \mathrm{C}$, and $15 \mathrm{ml}$ aliquots were taken at intervals. The reaction was terminated by adding $1.5 \mathrm{ml}$ of $0.4 \mathrm{M}$ EDTA (pH 8.0) on ice. The control non-crosslinked samples (the zero-time product) were prepared by mixing the reaction mixture with EDTA before addition of the enzyme. The formation of crosslinked caseins was followed by measuring the ammonia released and by analyzing the products with SDS-polyacrylamide gel electrophoresis. For other experiments using crosslinked proteins, the terminated reaction mixtures were heated for $3 \mathrm{~min}$ in boiling water and then dialyzed extensively against distilled water. Dialysates were lyophilized and stored at room temperature.

Determination of ammonia. Ammonia released during the crosslinking reaction was determined enzymically by the use of bovine liver glutamate dehydrogenase. Aliquots of 0.1 to $1.0 \mathrm{ml}$ of the terminated reaction mixtures were brought to a final volume of $2 \mathrm{ml}$ in assay mixtures containing $0.1 \mathrm{M}$ Tris- $\mathrm{HCl}$ buffer (pH 8.0), $10 \mathrm{~mm} \alpha$-ketoglutarate, $0.25 \mathrm{~mm} \mathrm{NADH}$, and 19.2 units of glutamate dehydrogenase. After $1.5 \mathrm{hr}$ at $25^{\circ} \mathrm{C}$, the decrease in absorbance was measured at $340 \mathrm{~nm}$. Ammonia was estimated using a molar extinction coefficient for NADH of $6.22 \times 10^{3}$.

Determination of amino groups. The number of free amino groups ( $\varepsilon$-amino groups of lysyl residues and $N$-terminal amino groups) of the protein was determined by the trinitrobenzenesulfonate method ${ }^{24)}$ with minor modifications. One $\mathrm{ml}$ of sample solution to be analyzed, $1 \mathrm{ml}$ of $4 \% \mathrm{NaHCO}_{3}$, and $1 \mathrm{ml}$ of $0.05 \%$ trinitrobenzenesulfonate were mixed and kept in a dark place at $37^{\circ} \mathrm{C}$ for $5 \mathrm{hr}$. Absorbance at $340 \mathrm{~nm}$ was measured after adding $1 \mathrm{ml}$ of $1 \mathrm{~N} \mathrm{HCl}$ containing $5 \%$ 
SDS to the reaction mixture.

SDS-polyacrylamide gel electrophoresis. Polyacrylamide gel electrophoresis in SDS was carried out on column gels $(3 \%$ stacking gel and $10 \%$ separating gel) or on slab gels (2\% stacking gel and $3 \sim 25 \%$ gradient separating gel) using the SDS-Tris-glycine discontinuous buffer system described by Laemmli. ${ }^{25}$ ) Prior to electrophoresis, the sample proteins were incubated at $90^{\circ} \mathrm{C}$ for $3 \mathrm{~min}$ in the presence of $2 \% \mathrm{SDS}$, $10 \%$ glycerol, $5 \%$ 2-mercaptoethanol, and $0.002 \%$ bromophenol blue. The column gel electrophoresis was done at a constant current $(4 \mathrm{~mA}$ per gel for $100 \mathrm{~min}$ ) and the slab gel electrophoresis at a constant voltage ( $40 \mathrm{~V}$ for $1 \mathrm{hr}$ and $120 \mathrm{~V}$ for the next $8 \mathrm{hr}$ ). The column gel was stained with $0.5 \%$ amido black $10 \mathrm{~B}$ in $20 \%$ acetic acid, and the slab gel with $0.1 \%$ Coomassie brilliant blue in $50 \%$ trichloroacetic acid. Both gels were destained in $7 \%$ acetic acid.

Ultracentrifugation. Sedimentation analyses were performed at $35^{\circ} \mathrm{C}$ with a Beckman model $\mathrm{E}$ analytical ultracentrifuge. Lyophilized caseins were dissolved in $10 \mathrm{~mm}$ imidazol buffer (pH 7.1) containing $70 \mathrm{~mm} \mathrm{KCl}$ and $2 \mathrm{~mm}$ dithiothreitol.

Precipitation of $\alpha_{\mathrm{s1}}$ - and $\beta$-caseins. The precipitation of $\alpha_{\mathrm{s1}}$ - and $\beta$-caseins caused by $\mathrm{CaCl}_{2}$ was tested as follows. The reaction mixture contained, in a total volume of $1.0 \mathrm{ml}, 2.5 \mathrm{mg} / \mathrm{ml}$ lyophilized casein component, $10 \mathrm{~mm}$ imidazol buffer (pH 7.1), $70 \mathrm{~mm} \mathrm{KCl}$, and $0 \sim 25 \mathrm{mM} \mathrm{CaCl}_{2}$. After preincubation of the protein solution for $10 \mathrm{~min}$ at $37^{\circ} \mathrm{C}, 200 \mathrm{mM} \mathrm{CaCl}$ was added to the desired concentration. The reaction mixture was further incubated for $1 \mathrm{hr}$ and centrifuged at $2000 \mathrm{rpm}$ for $1 \mathrm{~min}$ at the same temperature. The amount of protein in the supernatant was determined from the absorbance at $280 \mathrm{~nm}$ after dilution with $50 \mathrm{~mm}$ potassium citrate.

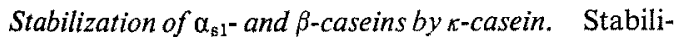
zation against precipitation in the presence of $\mathrm{CaCl}_{2}$ of $\alpha_{\mathrm{s} 1}$ and $\beta$-caseins by $\kappa$-casein was tested under the same conditions as in the precipitation experiments, except that the reaction mixture contained $25 \mathrm{mM} \mathrm{CaCl}_{2}$ and 0.125 to $0.625 \mathrm{mg} / \mathrm{ml} \kappa$-casein. The amount of $\alpha_{\mathrm{s} 1^{-}}$or $\beta$-casein in the supernatant was calculated by subtracting the amount of added $\kappa$-casein from the total protein in the supernatant.

\section{RESULTS AND DISCUSSION}

\section{Crosslinking of casein components}

The transglutaminase reaction with each casein component was followed by estimating the ammonia released by the protein (Fig. 1).

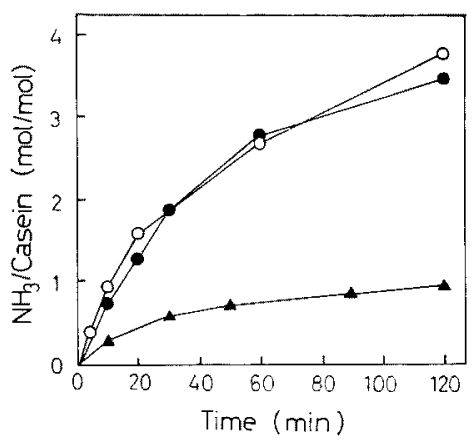

FIG. 1. Transglutaminase Reaction with Casein Components.

The determination of ammonia and the conditions of the reaction were as given in MATERIALS AND METHODS (-) $\alpha_{s 1}$-casein; $(\bigcirc-O) \beta$-casein; $(\Lambda-\Lambda) k$-casein.

Both $\alpha_{\mathrm{s} 1^{-}}$and $\beta$-caseins had the same high reactivity, but a much lower reactivity was found for $\kappa$-casein. Since amine was not added to the transglutaminase reaction system, the amount of ammonia released during the reaction corresponds to the number of interor intramolecular $\varepsilon$-( $\gamma$-glutamyl)lysyl crosslinks formed by the action of the enzyme on casein. ${ }^{26)}$ Figure 1 shows that, after 120 min under the experimental conditions mentioned above, 3.5 $\varepsilon$-( $\gamma$-glutamyl)lysyl crosslinks per molecule were formed with $\alpha_{s 1}$-casein, 3.8 with $\beta$-casein, and 1.0 with $\kappa$-casein. With each casein component, the amount of ammonia released during the reaction corresponded to the decrease of free amino groups (Table I).

At present, the reasons for the lesser reactivity of $\kappa$-casein are not clear. The numbers

\section{Table I. Amount of Ammonia Released and the Decrease in Free Amino Groups During the Transglutaminase Reaction}

Samples were 120 min products obtained from the transglutaminase reactions shown in Fig. 1. The number of free amino groups was determined by the method described in Materials and Methods.

\begin{tabular}{|c|c|c|}
\hline \multirow{2}{*}{ Casein } & \multicolumn{2}{|c|}{ Number (mol/mol of casein) of: } \\
\hline & $\begin{array}{l}\text { Ammonia } \\
\text { released }\end{array}$ & $\begin{array}{l}\text { Decrease of free } \\
\text { amino group }\end{array}$ \\
\hline$a_{\mathrm{s} 1}$ & 3.5 & 3.7 \\
\hline$\beta$ & 3.8 & 3.5 \\
\hline$\kappa$ & 1.0 & 0.6 \\
\hline
\end{tabular}


of glutaminyl and lysyl residues in the $\kappa$-casein molecule (Gln, 14; Lys, 9) are comparable to those of $\alpha_{\mathrm{s} 1}$-casein (GIn, 14; Lys, 14) and $\beta$ casein (Gln, 21; Lys, 11), so the concentrations of these residues in the reaction of each casein component are at the same level under experimental conditions. The data obtained from experiments using several native or denatured proteins and a labeled low molecular weight amine $\left(\left[{ }^{14} \mathrm{C}\right]\right.$ glycine ethyl ester) as substrates have suggested that the substrate effectiveness

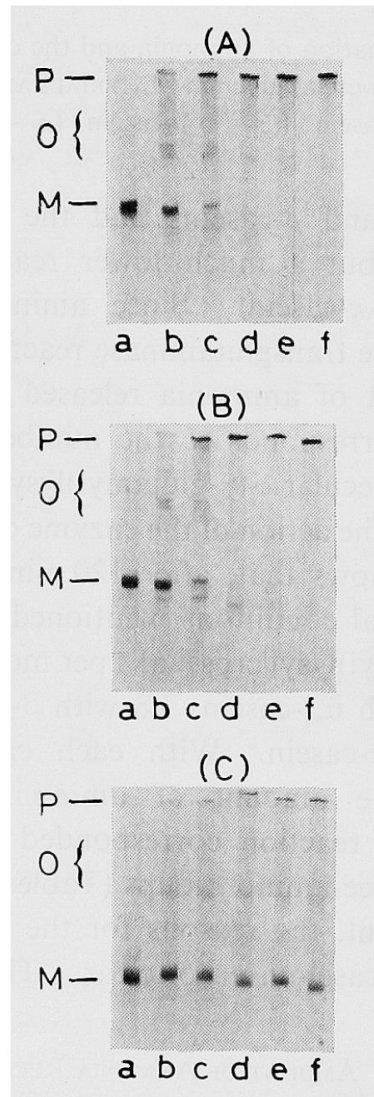

FIG. 2. SDS-Polyacrylamide Gel Electrophoretic Patterns of Casein Components during the Transglutaminase Reaction.

Samples were obtained from the transglutaminase reactions shown in Fig. 1. $40 \mu \mathrm{g}$ of protein was applied to each column. Migration is from top to bottom. $\mathrm{M}, \mathrm{O}$, and $\mathrm{P}$ indicate the positions of bands of monomers, oligomers, and polymers.

(A) $\alpha_{s 1}$-casein; samples on gels $\mathrm{a} \sim \mathrm{f}$, incubated with transglutaminase for $0,10,20,30,60$, and $120 \mathrm{~min}$, respectively. (B) $\beta$-casein; a $\sim \mathrm{f}$, for $0,4,10,20,60$, and $120 \mathrm{~min}$. (C) $k$-casein; $\mathrm{a} \sim \mathrm{f}$, for $0,10,30,50,90$, and $120 \mathrm{~min}$. of the peptide-bound glutaminyl residue depends not on the primary structure of the polypeptide containing the glutaminyl residue but on its conformation. ${ }^{27}$ ) Bovine casein components have been thought to have a disordered structure. ${ }^{28\}}$ Recently it was postulated that $\kappa$-casein has a fairly ordered structure. ${ }^{29)}$ It is possible that most of the glutaminyl and lysyl residues of $\kappa$-casein are buried inside the molecule and thus inaccessible to transglutaminase.

Changes in the molecular size of casein components during the transglutaminase reactions shown in Fig. 1 were analyzed by SDS-polyacrylamide gel electrophoresis. In all cases, as the reaction proceeded, the monomer content decreased and the polymer content increased (Figs. 2, 3). In the cases of $\alpha_{\mathrm{s}_{1}}$ and $\beta$-caseins, the formation of oligomer was observed during the first $30 \mathrm{~min}$, and by $120 \mathrm{~min}$ all monomers and oligomers were turned to polymers. With $\kappa$-casein, only about $60 \%$ of the monomers had changed into oligomers and polymers after $120 \mathrm{~min}$. When the enzyme concentration is elevated, all of the $\kappa$-casein is converted to polymer (data not shown). These results indicate the formation by transglutaminase of intermolecular crosslinks for each of the casein components.

In the early reaction steps of $\alpha_{\mathrm{s} 1}$ - and $\beta$-caseins (during the first $30 \mathrm{~min}$ with $\alpha_{\mathrm{s1}}$-casein, and

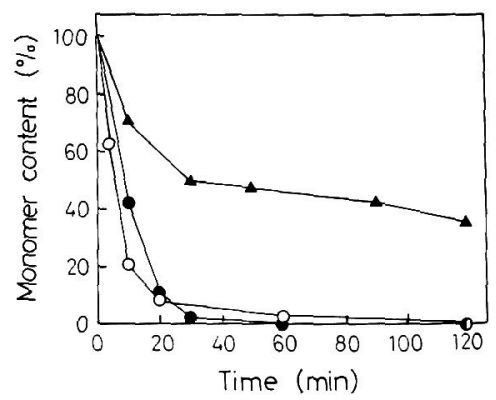

FIG. 3. Monomer Content of Casein Components during the Transglutaminase Reaction.

The disappearance of the monomer bands shown in Fig. 2 was analyzed quantitatively with densitometer tracings. The monomer content (in \%) is based on the amount obtained from each gel loaded with zerotime product.

$(\bullet-\bullet) \alpha_{s 1}$-casein; $(0-0) \beta$-casein; $(\mathbf{\Lambda}-\mathbf{\Lambda}) \kappa$-casein. 


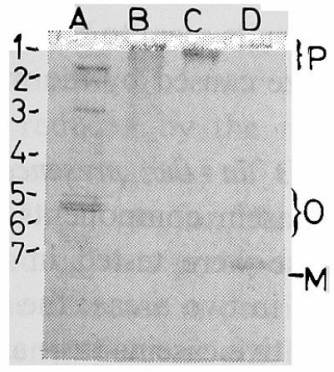

FIG. 4. SDS-Polyacrylamide Gradient Gel Electrophoresis of Polymer Products.

Samples were the 120 min products obtained from the transglutaminase reactions shown in Fig. $1.40 \mu \mathrm{g}$ of protein was applied to each lane. Migration is from top to bottom. $\mathrm{P}, \mathrm{O}$, and $\mathrm{M}$ indicate the position of bands of polymer, oligomer, and monomer. (A) Standard proteins; (1) thyroglobulin $(669,000)$, (2) ferritin $(440,000)$, (3) $1 / 2$ thyroglobulin $(330,000)$, (4) lactate dehydrogenase $(140,000)$, (5) bovine serum albumin $(67,000),(6) 1 / 4$ catalase $(60,000),(7) 1 / 4$ lactate dehydrogenase $(36,000)$. (B) $\alpha_{\mathrm{sl}}$-casein. (C) $\beta$ casein. (D) $\kappa$-casein.

during the first $60 \mathrm{~min}$ with $\beta$-casein), bands with higher mobility than that of the monomer band were detected, and, with each of the caseins, the mobility of the oligomer bands did not indicate a molecular weight corresponding to an integral multiple of the monomer molecular weight by calibration with standard proteins. The formation of intramolecular crosslinks might bring about an abnormal mobility in SDS-polyacrylamide gel of the protein molecules.

To determine the molecular weight of the polymer products, each of the 120 min products was subjected to SDS-polyacrylamide gradient gel electrophoresis (Fig. 4). From a standard curve (not shown) drawn from the electrophoretic mobilities of proteins of known molecular weight, the molecular weights of $\alpha_{\mathrm{s}_{1}}-$, $\beta$, and $\kappa$-casein polymer products were calculated to be $5.0 \sim 10 \times 10^{5}$. $\alpha_{\mathrm{s} 1}$-Casein had heterogeneous bands, while $\beta$ - and $\kappa$-caseins had homogeneous ones indicating molecular weights of $8.8 \times 10^{5}$ and $10 \times 10^{5}$, respectively.

\section{Properties of crosslinked casein components}

Each of the casein components forms soluble polymers by self-association, and $\alpha_{\mathrm{s} 1^{-}}$and $\beta$ caseins form soluble complexes with $\kappa$-casein. In the presence of calcium ions, $\alpha_{\mathrm{s1}^{-}}$and $\beta$ caseins precipitate as the calcium caseinates, and $\kappa$-casein stabilizes these calcium caseinates against precipitation as casein micelles. Therefore, the properties of casein components modified by transglutaminase were examined in the presence and in the absence of calcium ions. The samples used in these experiments were products of the transglutaminase reactions shown in Fig. 1.

1) Properties in the absence of $\mathrm{CaCl}_{2}$. In ultracentrifugal experiments, effects of the modification by transglutaminase on the selfassociation of casein components were studied in the absence of calcium ions. Figure 5 shows sedimentation patterns of casein components in the presence of $70 \mathrm{mM} \mathrm{KCl}$ and $2 \mathrm{~mm}$ dithiothreitol at $35^{\circ} \mathrm{C}$. After modification, sedimentation coefficients $\left(S_{35}\right)$ of $\alpha_{s 1}$-caseins increased from $4.9 \mathrm{~S}$ to $8.3 \mathrm{~S}$ and of $\beta$-caseins from $14.9 \mathrm{~S}$ to $20.4 \mathrm{~S}$. These results indicate that, under our experimental conditions, each of the modified components exists as a larger
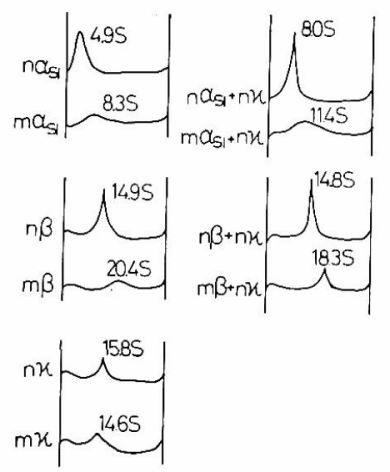

FIG. 5. Sedimentation Patterns of Casein Components.

Samples were from the transglutaminase reactions shown in Fig. 1. " $n$ " represents native protein (zerotime product) and " $\mathrm{m}$ " the modified protein (120 min product). Centrifugation was performed at $35^{\circ} \mathrm{C}$ in $10 \mathrm{~mm}$ imidazol buffer (pH 7.1) containing $70 \mathrm{~mm} \mathrm{KCl}$ and $2 \mathrm{~mm}$ dithiothreitol. The concentration of each casein component was $5 \mathrm{mg} / \mathrm{ml}$. The pictures were traced from photographs taken $18 \pm 1 \mathrm{~min}$ after reaching maximum speed $(60,000 \mathrm{rpm})$. Values in this figure are $S_{35}$. 
molecular species than a self-associate of the corresponding native component would be. The degree of self-association of the modified component is not known at present. With $\kappa$-casein, the sedimentation coefficient did not change significantly, probably because modification was slight. Figure 5 also shows that each of the modified $\alpha_{\mathrm{s} 1^{-}}$and $\beta$-caseins can form complexes with $\kappa$-casein as well as the native ones could. Sedimentation coefficients of the complexes of modified components were larger than that of the complex from native ones. These results seem to reflect the increase in molecular size caused by the modification.

2) Properties in the presence of $\mathrm{CaCl}_{2}$. Properties of casein components modified by transglutaminase were tested in the presence of calcium ions in two areas; the precipitation of calcium-sensitive caseins ( $\alpha_{81}$ - and $\beta$-caseins) in the presence of $0 \sim 25 \mathrm{mM} \mathrm{CaCl}_{2}$, and the stabilization by $\kappa$-casein of $\alpha_{s 1^{-}}$and $\beta$-caseins

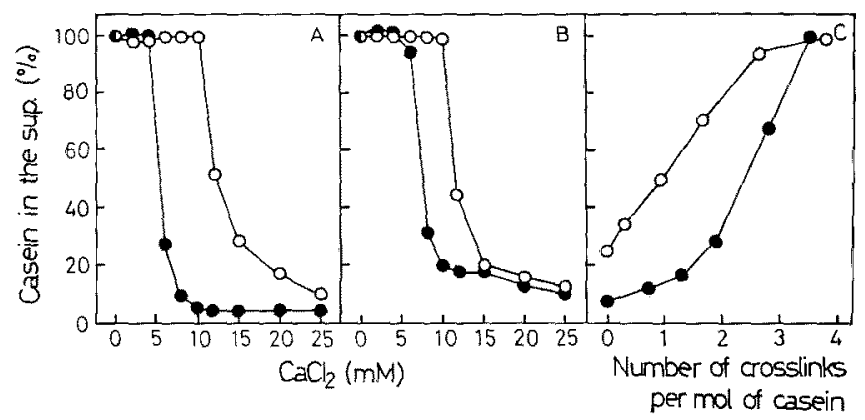

FIG. 6. Effect of Modification by Transglutaminase on the Precipitation of $\alpha_{\mathrm{s} 1}$ - and $\beta$-Caseins in the Presence of $\mathrm{CaCl}_{2}$.

Precipitation was tested as described in MATERIALS AND METHods. The percentage content of the casein in the supernatant was based on the amount obtained in the absence of $\mathrm{CaCl}_{2}$. Samples were from the transglutaminase reactions shown in Fig. 1.

(A) $\alpha_{\mathrm{s} 1}$-casein; (-) not modified (zero-time product), $(\mathrm{O}-\mathrm{O})$ modified (120 min product). (B) $\beta$-casein; (- - ) not modified (zero-time product), $(\mathrm{O}-\mathrm{O})$ modified $(120 \mathrm{~min}$ product). (C) Relationship between precipitation in the presence of $10 \mathrm{mM} \mathrm{CaCl}$ and the extent of modification; $(-\bullet) \alpha_{s t}$-casein, $(\bigcirc-O) \beta$-casein.

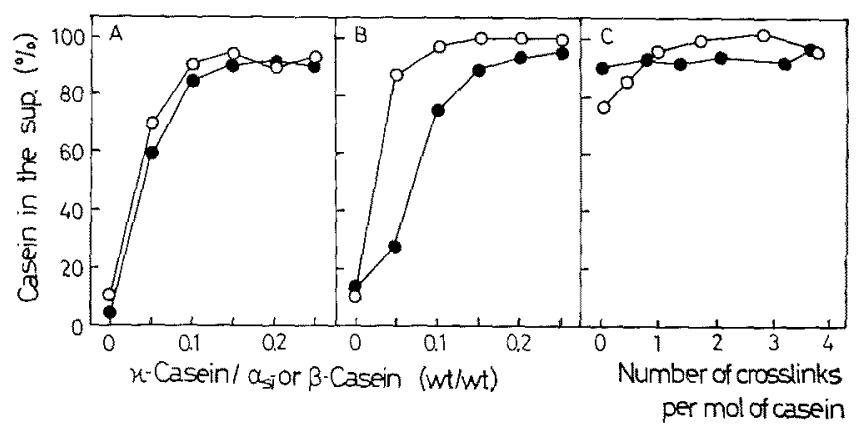

FIG. 7. Effect of Modification by Transglutaminase on the Stabilization of $\alpha_{s 1^{-}}$and $\beta$-Caseins by $\kappa$-Casein.

Stabilization by $x$-casein was tested as described in Materiats ANd Methods. The percentage content of the casein in the supernatant was based on the amount obtained in the absence of $x$ casein. Samples were from the transglutaminase reactions shown in Fig. 1.

(A) $\alpha_{\mathrm{s} 1}$-casein; $(--)$ not modified (zero-time product), $(\mathrm{O}-\mathrm{O})$ modified (120 min product).

(B) $\beta$-casein; (- ) not modified (zero-time product), $(\mathrm{O}-\mathrm{O})$ modified (120 min product). (C) Relationship between stabilization by $\kappa$-casein and the extent of modification. The ratio of the amount of $\kappa$-casein to the amount of $\alpha_{\mathrm{si}}$ - or $\beta$-casein was $0.1 ;(-\infty) \alpha_{\mathrm{s} 1}$-casein, $(0-0) \beta$-casein. 
against precipitation in the presence of $25 \mathrm{mM}$ $\mathrm{CaCl}_{2}$. Figure 6 shows that precipitation of $\alpha_{81^{-}}$and $\beta$-caseins at lower concentrations of $\mathrm{CaCl}_{2}$ was reduced by the modification but, at higher concentrations of $\mathrm{CaCl}_{2}(25 \mathrm{mM}$ for $a_{\mathrm{s} 1}$-casein, $15 \sim 25 \mathrm{~mm}$ for $\beta$-casein), both native and modified caseins precipitated to the same extent. The decrease in precipitation at lower $\mathrm{CaCl}_{2}$ concentrations might be caused by an increase in the negative net charge or by the restriction of $\mathrm{Ca}^{2+}$-induced conformational changes in the modified casein components. Figure 7 shows that both native and modified $\alpha_{\mathrm{s} 1}$-caseins were stabilized by $\kappa$-casein in the same manner, and $\beta$-casein turned out to be stabilized more easily. The modification of $\kappa$-casein, the extent of which is very low (Fig. 1), did not affect its stabilizing ability on both $\alpha_{\mathrm{s} 1^{-}}$and $\beta$-caseins (data not shown).

The results above indicate that transglutaminase polymerizes each of the casein components by the formation of intermolecular cross-links, but that it does not impair their functional properties exhibited in both the presence and the absence of calcium ions. This suggests that transglutaminase is a useful tool to change the rheological properties of caseins without damaging their special functional properties, and that it can also be used to localize the casein components in the casein micelle structure.

Transglutaminase will be useful for producing food protein materials with new functional properties and high nutritive values through the formation of complexes between proteins from different sources and through the introduction of primary amines, including amino acid esters, to proteins. These areas are under investigation.

\section{REFERENCES}

1) J. E. Folk and S. I. Chung, "Advances in Enzymology," Vol. 38, ed. by A. Meister, John Wiley \& Sons Inc., New York, N. Y., 1973, p. 109.

2) J.E. Folk and J.S. Finlayson, "Advances in Protein Chemistry," Vol. 31, ed. by C. B. Anfinsen, J. T. Edsall and F. M. Richards, Academic Press Inc., New York, N. Y., 1977, p. 1.

3) L. Lorand, Ann. N. Y. Acad. Sci., 202, 6 (1972).
4) H. G. Williams-Ashman, A. C. Notides, S. S. Pabalan and L. Lorand, Proc. Natl. Acad. Sci. U.S.A., 69, 2322 (1972).

5) L. Lorand, L. B. Weissmann, D. L. Epel and J. Bruner-Lorand, Proc. Natl. Acad. Sci. U.S.A., 73, 4479 (1976).

6) R. H. Rice and H. Green, J. Cell Biol., 76, 705 (1978).

7) A. Dutton and S. J. Singer, Proc. Natl. Acad. Sci. U.S.A., 72, 2568 (1975).

8) L. Lorand, R. Shishido, K. N. Parameswaran and T. L. Steck, Biochem. Biophys. Res. Commun., 67, 1158 (1975).

9) V. Iwanij, Eur. J. Biochem., 80, 359 (1977).

10) A. Dutton, E. D. Rees and S. J. Singer, Proc. Natl. Acad. Sci. U.S.A., 73, 1532 (1976).

11) T. Okumura and G. A. Jamieson, J. Biol. Chem., 251, 5944 (1976).

12) J.S. Pober, V. Iwanij, E. Reich and L. Stryer, Biochemistry, 17, 2163 (1978).

13) G. J. Brewer and S. J. Singer, Biochemistry, 13, 3580 (1974).

14) D. L. Gard and E. Lazarides, J. Cell Biol., 81, 336 (1979).

15) J. R. Whitaker, "Food Proteins-Improvement though Chemical and Enzymatic Modification," ed. by R. E. Feeney and J. R. Whitaker, American Chemical Society, 1977, p. 95.

16) J. M. Connellan, S. I. Chung, N. K. Whetzel, L. M. Bradley and J. E. Folk, J. Biol. Chem., 246, 1093 (1971).

17) H. Waelsch and M. J. Mycek, "Methods in Enzymology," Vol. 5, ed. by S. P. Colowick and N. O. Kaplan, Academic Press Inc., New York, N. Y., 1962, p. 833.

18) J. E. Folk, "Methods in Enzymology," Vol. 17A, ed. by H. Tabor and C. W. Tabor, Academic Press Inc., New York, N. Y., 1970, p. 889.

19) M. Yoshikawa, E. Sugimoto and H. Chiba, Agric. Biol. Chem., 38, 1005 (1974).

20) J. C. Mercier, F. Grosclaude and B. RibadeauDumas, Eur. J. Biochem., 23, 41 (1971).

21) F. Grosclaude, M. Maha and B. Ribadeau-Dumas, ibid., 40, 323 (1973).

22) B. Ribadeau-Dumas, G. Brignon, F. Grosclaude and J. C. Mercier, ibid., 25, 505 (1972).

23) J. C. Mercier, G. Brignon and B. RibadeauDumas, ibid., 35, 222 (1973).

24) K. Satake, T. Okuyama, M. Ohashi and T. Shinoda, J. Biochem., 47, 654 (1960).

25) U. K. Laemmli, Nature, 227, 680 (1970).

26) A. Neidel, M. J. Mycek, D. D. Clarke and H. Waelsch, Arch. Biochem. Biophys., 77, 227 (1958).

27) H. Toda and J. E. Folk, Biochim. Biophys. Acta, 175, 427 (1969).

28) T. T. Herskovitz, Biochemistry, 5, 1018 (1966).

29) M.-H. Loucheux-Lefebvre, J.-P. Aubert and P. Jollés, Biophys. J., 23, 323 (1978). 